\title{
Formation of Post-conflict Georgian identities Case: Abkhazian War and August War
}

\author{
Nino Tabeshadze \\ GIPA - Georgian Institute of Political Affairs, Tbilisi, Georgia, tbshdz@yahoo.com
}

\begin{abstract}
Modern Georgian history knows two devastating conflicts which happened in recent years bringing much confusion and disorientation to local Georgian Community. Given article tries to explore the identity crisis which took place after the two wars. As a result of military actions great number of people was obliged to leave their homes and move in temporary shelters. It took only several days to become IDP's (Internally Displaced Persons) from regular citizens. This naturally led to questioning the role of self in community. Such major events as mass trauma generally change the perception of reality and Georgia was no exception. In an attempt to overcome painful experiences individuals create different responses to traumatic experiences but we have the opportunity to compare two narratives depicting the emotions of IDPs from two different conflicts. Major aim of the article is to see whether there are any similarities between the perceptions of two different historical events: How IDPs explain the events and their own emotions.
\end{abstract}

KEYWORDS: War, Trauma, Coping, PTSD, Identity

\section{Introduction and Literature Preview}

The last ten years have shown growing interest of scholars towards the issues of trauma and postconflict identity formation. More and more scientists understand the role of interdisciplinary approach in exploring the concepts and historical events. Therefore, cultural aspects became especially significant in war studies (Summerfield 2001, 78). In order to understand the profound link between the culture, identity and mass trauma, one should explain all the terms. Even though the definition of culture consists of more than 300 different definitions, we try to explore the concept with the most widespread explanation used by Merriam-Webster dictionary:

- "The customary beliefs, social forms and material traits of a racial, religious, or social group.

- Also: the characteristic features of everyday existence shared by people in a place or time.

- The integrated pattern of human knowledge, belief, and behaviour that depends upon the capacity for learning and transmitting knowledge to succeeding generation".

All those definitions lead us to thinking that culture is a very complex and hard concept to grasp. It represents the matrix or the worldview where every person or the community tries to find itself. That is where identity appears: It supports the individual in finding the bonds with the past, identifying the links with present and helps in predicting the future position (Butler 2004, 20). Identity is widely seen as the individual's concept of self, as well as the individual's interpretation of the social definition of the self, within his/her inner group and larger society (Kim 2003, 6). Identity is a collective term for the roles, goals and values that people adopt in order to give their lives direction and purpose. Of course when traumatic event happens, it can disrupt these plans and alter our lives in unpredictable and sometimes permanent ways.

Mass traumas (collective traumas) are shocking, unexpected events happening in short time and changing the life of whole society by introducing the dimensions of fear, disorientation and destruction of old lifestyle. Such events affect large numbers of people either directly or indirectly. It is beyond the scope of individual traumatic experiences. Mass traumas include large-scale natural and human-caused disasters such as wars. Mass traumas may involve significant loss of property and lives as well as the widespread disruption of normal routines and services. Responding to such traumas often require immediate and extensive resources. Mass traumas can create an immediate sense of commonality - many people share the same experience (Kopstein, \& White 2014, 12).

Our identity can shape the way we perceive, interpret and experience the trauma. Traumatic experiences can alter ones identity. Not only can our identity affect the way we perceive the event, but it can also shape the way we recover from the event. As noted above, trauma can disrupt one's 
sense of identity, but on the other hand, one's identity can affect the way one perceives and recovers from the trauma. The trauma, however, can also become incorporated into one's identity. Trauma can be viewed as a turning point in life, or as a reference point for expectations about the future (Berman 2016).

Large-scale traumas are often referred to as "acts of God", or, in cases of other international events, as the "Act of Evil". Political terror and war are likely to have lasting consequences for survivors. In essence, anything that threatens the existence, beliefs, well-being or livelihood of a community, is likely to be experienced as traumatic by community members. When terrible things happen, it is human nature to assign blame. Trauma survivors can become heavily invested in assigning blame or finding out who was at fault, regardless of the type of trauma. Culture strongly influences the perceptions of trauma. For example, sudden death of a family member or loved one can be less traumatic in a culture that has a strong belief in a positive afterlife (Kopstein, White 2014, 10).

Under the stress, the forces that define "us" and "them" could quickly regress into the humiliating and killing of "others" and that large groups would respond at times with violence in order to erase the threats to their sense of "weness". Or, they would simply be murderous in order to maintain an illusion of superiority over those who they openly or secretly felt to be inferior or less human (Volkan 2012, 57). This act can be done symbolically, verbally or mentally as well in order to erase the threatening "others". This can explain the hatred towards the military opponents which posttraumatic narratives of Georgia depict. When the disaster fades from headlines, public attention and concern are likely to decrease, leaving survivors struggling to reestablish or reinvent their lives without much acknowledgement.

The concept of trauma is more complicated than the brief description. To simply label peoples as suffering from PTSD (Posttraumatic Stress Disorder - effect of traumatic event of society and individuals) takes our attention away from an examination of individual and specific responses to traumatic events. For example, some people deal with trauma through creativity, while others are doomed to repeat it in symbolic fashions. Still, others separate and put their traumatized selves, in a sense, in an envelope (called dissociation) and go about behaving as if nothing has happened (Volkan 2012, 54). Examples of dissociation could easily be seen in 2008 during the war days. Part of Georgian society refused to accept the fact of ongoing war and was preserving the familiar routine. The other part of the community was heavily criticizing the people who chose to dissociate themselves unconsciously.

Traumatic events that IDPs experienced come under the umbrella of shared trauma that are connected with ethnic sentiments and that activate large-group identity issues. Not all of the IDPs are traumatized as individuals; they were traumatized because they belong to a certain specific ethnic group; shared traumatic events, which are connected with large-group identity issues, are always contaminated with shame and humiliation. Such traumas are also accompanied by a combination of great emotional (abstract) and concrete losses, such as the loss of relatives or friends, homes, dogs and even gardens (Volkan 2012, 87). That can be the reason for persisting melancholy and nightmares recorded in IDPs. PTSD is undoubtedly connected with severe loss and stressful experience. On the other hand, it could be the sign for the people to start natural fighting for the new life.

Personal growth after PTSD and changes in personality became especially interesting for scholars during the last 20 years. Phenomenon related to growth connected with PTSD was defined in literature with different terms: Stress-related growth, transformation, conscious benefit etc (Tedeschi and Calhoun $2004,5)$. Stress-related growth is connected to social support, which helps individual in sharing the experience and exploring the positive aspects of negative event.

During the last ten years due to two large-scale military conflicts (1991-1993, 2008) Georgia ended up having two waves of IDPs. According to UNICEF records, only after the war of 2008 more than 160000 people left homes. Most of IDPs faced very dangerous events and after the war there was insult, captivity, loss of homes, relatives, territories. In order to understand, how post-traumatic narratives responded to the needs of IDPs, we need brief timeline of events explaining the major milestones of Georgia's two military conflicts. 


\section{Brief Timeline}

Russia and Georgia were connected historically and geographically they represent neighbours. It is no surprise that those two communities came in close contact not once. In order to understand the historical context used in my article, I will offer brief timeline of major events connecting those two cultures. History of Georgian-Russian interaction can be divided in distant past, recent past and contemporary times. Close ties between two countries started in 1783 when Georgian kingdom formed an alliance with the Russian Empire, whereby the kingdom became a Russian protectorate and abjured any dependence on Persia. However, this agreement could not protect Georgia from Russian annexation in 1801 based on manifesto signed by Emperor Paul I. Georgia became independent briefly after separating from Russian Empire in 1918 and kept this independence until 1921 when after the Red Army invasion country was declared as Soviet Socialist Republic. One year later Soviets announced South Ossetia as autonomous region of Georgia which undoubtedly tensed relations between these two. In 1931 Abkhazia followed the path of Ossetia announcing autonomy. Georgia stayed as part of Soviet Union and gained independence with the help of referendum held on 31st of March of 1991. The same year military coup d'état against Georgian president took place.

Meanwhile, autonomous territories started to take actions: South Ossetia boycotted the elections of Georgian Supreme Council. As a result, Tbilisi declared the state of emergency in South Ossetia. Situation got complicated and resulted in war of South Ossetia in 1991-1992. The ceasefire agreement left South Ossetia divided into areas controlled by Georgia and areas controlled by the unrecognized government of South Ossetia. It also created the Joint Control Commission (including Georgia, Russia, North Ossetia and South Ossetia) and, under JCC mandate, introduced the joint peacekeeping forces (JPKF), made up of Georgian, Russian and Ossetia soldiers. A small number of organizations for Security and Co-operation in Europe monitors were also deployed in the area. At the same time in 1992 Abkhaz-Georgian war started which lasted until 1993. Georgian Parliament appealed to the UN, European Council and Supreme Council of the Russian Federation demanding the withdrawal of Russian forces from Abkhazia and stating that Russia waged "an undeclared war" against Georgia. The war resulted in declaration of Abkhazian de facto republic which is recognized internationally as part of Georgia. Heavy casualties were on both sides and 250,000 ethnic Georgian IDPs.

Contemporary history of Russo-Georgian relations is tightly connected to 2008. Events happening that year step by step led to full scale armed conflict. In April Russia declared it would step up ties with Abkhazia and South Ossetia, prompting Georgia to accuse Moscow of planning their de facto annexation. In May Russia sent 300 unarmed troops to Abkhazia, saying they were needed for railway repairs. Georgia accused Russia of planning military intervention. Georgian President Mikheil Saakashvili sent troops into South Ossetia in August. Russia moved its troops to the border, aircrafts flew over Georgia. Air strikes began in South Ossetia. On August 8 the United States, United Kingdom and NATO called for a cease fire of military hostilities by both Russia and Georgia. Delegation of EU and US diplomats flew to Georgia to resolve escalating tensions. As a result, Georgian president Saakashvili signed a cease fire agreement with Russia. The deal was brokered by French president Sarkozy. On August 16 Russian president Medvedev signed the cease fire agreement. Russia partially withdrew its troops from Georgia, as part of the cease fire agreement. Russia maintained soldiers at checkpoints near the disputed territories of Abkhazia and South Ossetia.

\section{Narratives}

Narratives are important in the study of trauma because they help individuals and groups create context for remembering, analyzing and overcoming stressful experience. Crystal states, that language is the primary index or symbol or register of identity, in that it expresses cultural distinctiveness (Crystal 2000, 33). As Zhang maintains "human thought or ideology is an important component of culture and because language is a medium to convey thought" (Zhang 2006, 42). Richard O'Kearney posits that traumatic narratives have specific features, including:

1. Emotionally fragile features; 
2. Fragmented recollection of events (disorder of structure);

3. Mixed time context (trauma causes fragmentation of memories, so it becomes impossible to keep clear structure);

4. Show who bears the responsibility (who is guilty in the things that happened);

5. Self-perception of the narrator (O'kearney 2006, 40).

Interestingly, after both: Abkhazian War and August War the narratives created in order to show the conflict details reveal the features of posttraumatic pieces of work. There are two very similar narratives depicting the stress and trauma as well as identity problems of particular groups of IDPs. Chronologically the first narrative of interest would be the one depicting the problems and identity crisis of the Abkhazian War IDPs. "A Heavy Burden" is the book developed jointly by the Internal Displacement Monitoring Centre; Norwegian Refugee Council in Georgia and Panos London Oral Testimony Program. 59 interviews were conducted by 12 interviewers selected from different communities affected by conflict.

The preface of book explains the title: 'A Heavy Burden' - it comes from the great weight of the war traumas that most narrators reveal. After years of displacement, narrators still need to share with the world their losses and their continuing grief. Unsolved problems of displacement cause the feeling of insecurity. This collection of stories reveals issues that go beyond typical displacement and protection needs and touches on values, issues of identity, feelings and emotions (Lois 2007). As the narrative was created by the participation of trained scholars, it includes selected interviews. The aim was to achieve a balance of different experiences of conflict and displacement. Firstly, scholars created master list to include the main characteristics of each narrator. A reading committee created by the project members to make the selection process as comprehensive, as possible. Eventually, out of 59 tape-recorded interviews 13 were selected for publication.

Emotional fragility, which is considered to be one of the main features of posttraumatic narratives, can be observed throughout the whole book:

"We left our village in September 1993 because the war began. Abkhazians occupied Sokhumi and three days later, Gali too. We left at the beginning of the conflict. I remember that day as though it was yesterday, but it was 14 years ago. My mother's godson said to me: Why do you cry? We will return after three days". The final words of interviewer are the persisting motives in both narratives. After every conflict or war the mainstream idea for the community is the idea of fast return. Until the trauma will be analyzed and the results will be accepted somehow, community and especially IDPs choose to dissociate from the experience. "They were killed for nothing - just because they were Georgians". However, this victim has overcome traumatic experience with the help of employment and support of the surrounding environment; that is why she calls for forgiveness "Let's forgive and shake hands".

Second speaker underlines the strict difference introduced between Georgians and Abkhazians during the war of Abkhazia. The imaginary border can be drawn between the situations before the conflict and during the war. At first: "There were quite a few Abkhazians at the wedding. You couldn't feel any tension at all between the two sides". Whereas, during the conflict: "Abkhazians found that man had Georgian ID and arrested him".

The conflict took place not only between the communities but also between the identities. One of the respondents remembers how the toastmaster was asked to say Georgia instead of Abkhazia in his toast - Long live our land. Instead, he said "Long live Georgia and Abkhazia" which underlines the conflicting existence of Abkhazia within the borders of Georgia. Interviewed person underlines the identity issue and how service of Georgian man might not be recognized by Abkhazians and vice versa. "When you serve in Georgian army, Abkhazian legislature doesn't acknowledge it. I am a Georgian man and I prefer to serve in the Georgian army rather than to be unacknowledged by Georgians or the Georgian legislature after serving the Abkhazian army". The respondent also mentions problems of stereotyping. Difference between the children "here" and "there" might not be huge, but it still exists: "Children here are more advanced, as for there, they don't have any ability to think independently". Second interview perfectly reveals the group who is responsible for tragedies of people's lives: "Once, the Abkhazians attacked the village, perhaps to steal something or take something away". 
How has the condition changed in Abkhazia after the conflict? "Time has stopped there. It's come to a standstill. There's nothing like progress _ only regression. You can't start a business there. There are no educational opportunities there". Even though life on this side of the river is not perfect either, victims refer to some opportunities for improvement while on the other side offers no perspective at all. "My family has contacts with the Abkhazians, but these contacts are based on vertical relationship - it's like a relationship between the master and his servant". The respondent feels that his life has changed drastically due to the conflict and as a child he experienced some problems of self-perception and selfesteem. "I lost a lot. I lost the prospect of better future. I might have been more successful if we had not been displaced, because I wouldn't have those problems. I am sure I would achieve much more. The displacement was devastating not only for my family, but for many other families as well".

As it is mentioned in the book, the ethnic identity is directly connected to ones social status in society and the treatment they are receiving from the oppressors. "Ethnic background determines the treatment towards people there. Our Georgian population is treated as if they were low-class. It's wrong but if you're Abkhazian, you're considered to have a higher social status than if you're a Georgian. If I tell them I am Georgian, I might be arrested".

Overall, the book shows classical signs of posttraumatic narratives by revealing some of the major features characteristic for posttraumatic pieces of literature such as: giving the detailed account of particular memories, describing the condition after war, naming the enemy and talking about the selfperception problems. But eventually the book "A Heavy Burden" can be considered as a positive narrative by the reader due to having a hope for reconciliation and better future: "We will be reconciled", "We have a hope for the future". We can see that the stress has been managed with the time and with the help of different organizations/individuals working closely with IDP families.

The second narrative of interest is pretty different in its context and trauma perception. It was created right after the traumatic event of August War in 2008. The book is symbolically called "Hero"title, which shows the importance of loss for Georgian community. The soldiers deceased in war became the heroes fighting for the freedom and independence of their country and narrative tries to express it. The book "Hero" contains up to 300 stories. The stories were written by the victim's families and gathered by Georgian press association. Each storyteller tries to describe event in details. Apart from that each story is accompanied by the brief biography of the soldiers along with their photos. "Hero" makes clear differentiation between the group of victims and the group of enemies. It openly accuses Russia in wrongdoings, killings, mass murders etc. Trauma is generalized in whole book linking it not only with direct victims but also to their families and, therefore, to large society (indirect victims) (Tabeshadze 2016, 33). Considering all the above-mentioned, we can safely assume that "Hero" belongs to posttraumatic narratives.

Dissociation is a common feature for the book "Hero" as well. We meet the episodes in the book where the family members refuse to accept the fact of trauma and the death of their family members at all. "I am not going to dress in black. I am waiting for my son" or "I am sitting by the window waiting for my husband. The boys told me he was lost, but believe he will come back" (Fkhakadze 2010, 18). The book tries to define the group of heroes and the group of demons. Russians are named as the group of "Others", who bring every misfortune and destruction. Therefore, they are responsible for the suffering of the victims.

As noted earlier, searching for those to be blamed is inseparable part of traumatic experience. Perception of enemy or "others" is directly associated with the strengthening of the ethnic identity. The role of enemy is to be bad and almost all the stories of the book underline this. "Not only my son was killed by Russian bullet, but also his sons and his descendants which my son would have", "She thought her husband was destined to die, but instead, Russians killed him" or "In the buffer zone Russian Soldiers told her: your son will never wear a uniform", "We had a protest against Russians and towards language as well".

The book underlines the supremacy of Georgians over Russians underlining the ethnic identity. For the victims heroic behaviour can only be characteristic to Georgians as the enemies are incapable of deeds: "Only Georgian can be such heroes. They stopped the enemy attack and made a shift to the battle. Russian general expressed regret that if he had such soldiers as Georgians had, he would 
definitely win the war" or "He sacrificed his life for his homeland and the enemies of his motherland killed him with bomb".

One more very interesting trend found throughout whole book is that the victims try to connect the war of 2008 with the war of Abkhazia referring to the similarity of their conditions, particularly, the loss of the people and territories. It might not be just a coincidence. War of Abkhazia also represents traumatic event for Georgian community and it also created huge number of IDPs. The special emphasis is on the heroes who fought in Abkhazian war before and afterwards they participated in August war. "He returned his Sokhumi in Tskhinvali. He crossed nine villages without any rest because he remembered Sokhumi" or "He barely survived death once in Abkhazia and finally could not escape from it in August War 2008".

Overall focus on heroism is persistent in whole narrative. Of course, the function of narrative is to inform wide society about the personal histories of the deceased soldiers. Moreover, personal histories also reflect the condition of the family members who also became the victims of mass trauma. This heroism is always underlined - in every story. "He did what heroes should - he protected the independence of his homeland" or "He became immortal on $10^{\text {th }}$ of August - he became a hero". Trauma is perceived as an opportunity to show one's heroic nature, it's a field to become immortal. Therefore, we can say that the book "Hero" is a classical example of posttraumatic narrative. With their detailed account of the event and showing the responsible group as well as with the emphasizing ethnic identity and emotional fragility both: "Hero" and "A Heavy Burden" stand in the group of posttraumatic narratives.

\section{Conclusion}

The major aim of the article was to analyze two narratives created after two devastating conflicts in Georgia. Attention was focused on two wars and their impact on whole society. Article assumes that both wars can be considered as mass trauma; otherwise they can be called collective traumatic events. These events, which are limited in time, cause not only destruction and disorientation - shift in established identity roles and change in values, but also the loss of many lives. Trauma, in general, is accompanied by loss and grief. This exact grief causes the PTSD - posttraumatic stress disorder characteristic for the family members of the victims. It is very important to deal with the PTSD, because neglecting trauma might cause additional problems for the individuals such as melancholy, depression, isolation and lack of desire for re-socialization.

After looking closely at two narratives dedicated to trauma commemoration, one can see clear difference. This difference includes more positive tone and neutral attitude towards the enemy in "A Heavy Burden" with overall hopeful tone for the future. On the other hand, the book "Hero" includes more disoriented view of events with vague perspectives of the future as well as more radicalism towards the enemy. I believe these differences might be caused by the time gone after the mass traumatic event. "A Heavy Burden" includes interviews about the events which happened more than a decade ago. "Hero" created in 2009 and published in 2010 contains stories of war which happened in 2008. This might be the cause of differences in radical positions and emotional tone. However, both narratives are undoubtedly posttraumatic with their main features.

To sum up, mass trauma and its different features are extremely interesting topic of study. Apart from that, trauma studies are important for traumatic societies in the process of recovery. Society's welfare and future reintegration of IDPs depends on the process of coping with PTSD. Narratives are inseparable parts of this process.

\section{References}

Berman, S. L. 2016. “Identity and Trauma.” J Trauma Stress Disorder Treat 5:2. Doi:10.4172/2324-8947.1000e108

Butler, J. 2004. "Undoing Gender.” Routledge, 14-23. https://selforganizedseminar.files.wordpress.com/2011/07/butlerundoing_gender.pdf.

Crystal, D. 2000. "Language Death.” Cambridge: Cambridge University Press.

Fkhakadze, T. 2010. "Hero." Tbilisi: Primetime Publishing, 13-56

Herman, Judith Lewis. 1992. "Trauma and Recovery”. London: Pandora Press.

Hunt, Noel. 2010. "War and Trauma.” Cambridge University Press: Cambridge. 
Kim, L.S. 2003. "Exploring the relationship between language, culture and identity." GEMA-Online Journal of Language Studies 3(2): 3-9.

Kopstein, A., White, D.K. 2014. "Substance Abuse and Mental Health Services Administration." Trauma-Informed Care in Behavioral Health Services 13-4801 (57): 6-18.

Lois, A. S., Tavartkiladze, T. 2007. "A Heavy Burden (Internally Displaced in Georgia: stories of people from Abkhazia and South Ossetia)", 27-85. Available at http://georgica.tsu.edu.gelfiles/03Society/IDPs/Lois\&Tavartkiladze-2007.pdf.

O’Kearney, R., Perrott. K. 2006. “Trauma narratives in posttraumatic stress disorder.” J 'Trauma and Stress' 19(1): 8193.

Summerfield, D. 2001. "The Invention of Post-traumatic Stress Disorder and the Social Usefulness of a Psychiatric Category”. BMJ: British Medical Journal 322(7278): 95-98. Available at http://dx.doi.org/10.1136/bmj.322. 7278.95 .

Sztompka, Piotr. 2004. “The Trauma Of Social Change.” London: University California Press Ltd.,300-480.

Tabeshadze, N. 2016. "Formation of Post-Traumatic Narrative Templates." International Journal of Humanities, Art and Social Studies (IJHAS) 3(2): 31-39.

Tedesci, G.R, Calhoun, G.L. 2004 "Posttraumatic Growth: Conceptual Foundations and Empirical Evidence." Psychological Enquiry 15(1): 1-18.

Volkan, V. 2012. "Killing in the Name of Identity: A Study of Bloody Conflicts." Pitchstone Publishing, 22-90

Zhang, J. 2006. "Socio-cultural Factors in Second Language Acquisition." Sino-U.S. English Teaching Journal 3(5): 41-42. 